\title{
ADOPSI PEKEBUNAN KARET TERHADAP PENGGUNAAN ASAM SEMUT SEBAGAI BAHAN KOAGULAN LATEKS DI KECAMATAN PEMALI KABUPATEN BANGKA
}

\author{
Adoption of Rubber Planters on the Use of Formic Acid as Latex Coagulant Material \\ in Pemali District, Bangka Regency
}

\author{
Linda Tri Wira Astuti ${ }^{1}$, Ameilia Zuliyanti Siregar ${ }^{1,2^{\star}}$, Khairul Ihsan $^{1^{*}}$ \\ ${ }^{1}$ Politeknik Pembangunan Pertanian Medan \\ JI. Binjai Km. 10, Tromolpos 18, Payageli, Kecamatan Sunggal, Kabupaten Deli Serdang, \\ Sumatera Utara, 20002 \\ ${ }^{2}$ Fakultas Pertanian Universitas Sumatera Utara \\ JI. Dr. A Sofyan No 3 Medan 20155, Sumatera Utara \\ *Email: ameiliazuliyanti@gmail.com, khairulihsan79@gmail.com
}

Diterima : 5 Oktober 2021; Direvisi: 8 November 2021; Disetujui : 31 Desember 2021

DOI :https://doi.org/10.37250/newkiki.v4i1.122

\begin{abstract}
This study aims to determine the level of adoption of smallholders and the factors that have a significant effect on the adoption of rubber planters in applying formic acid as a latex coagulant in Pemali District, Bangka Regency. This type of research is descriptive quantitative. The data collection methods are observation and interviews using a questionnaire that has been tested for validity and reliability, while the data analysis method uses a Likert scale and Logistics Regression Analysis. The variables used in this study are age, education, land area, characteristics of innovation, the role of extension workers, communication media, facilities and infrastructure, and the role of farmer groups. The results of the study showed that the adoption rate of rubber planters for the use of formic acid as a latex coagulant in Pemali District, Bangka Regency was in the low category with a percentage of $22.95 \%$. The results of the Logistics Regression Analysis showed that there was a significant influence between the variables of innovation characteristics, the role of extension workers, and infrastructure on the adoption opportunities for the use of formic acid as a latex coagulant in Pemali District, Bangka Regency.
\end{abstract}

Keywords: Adoption, Formic Acid, Latex Coagulant, Logistics Regression Analysis

\begin{abstract}
Abstrak
Penelitian ini bertujuan untuk mengetahui tingkat adopsi pekebun dan faktor-faktor yang berpengaruh signifikan terhadap adopsi pekebun karet dalam menerapkan asam semut sebagai bahan koagulan lateks di Kecamatan Pemali Kabupaten Bangka. Jenis penelitian ini adalah deskriptif kuantitatif. Metode pengumpulan data yaitu observasi dan wawancara menggunakan kuesioner yang telah diuji validitas dan reliabilitasnya, sementara metode analisis data menggunakan skala Likert dan Analisis Regresi Logistik. Variabel yang digunakan dalam penelitian ini yaitu umur, pendidikan, luas lahan, karakteristik inovasi, peran penyuluh, media komunikasi, sarana dan prasarana, dan peran kelompoktani. Hasil pengkajian menunjukkan bahwa tingkat adopsi pekebun karet terhadap penggunaan asam semut sebagai bahan koagulan lateks di Kecamatan Pemali Kabupaten Bangka termasuk kategori rendah dengan persentase 22,95\%. Hasil Analisis Regresi Logistik menunjukkan adanya pengaruh yang signifikan variabel karakteristik inovasi, peran penyuluh, dan sarana prasarana terhadap peluang adopsi penggunaan asam semut sebagai bahan koagulan lateks di Kecamatan Pemali Kabupaten Bangka.
\end{abstract}

Kata kunci: Adopsi; Asam Semut; Koagulan Lateks; Analisis Regresi Logistik

1210 | Khazanah Intelektual Volume 5 Nomor 3 Tahun 2021 
PENDAHULUAN

Tanaman

Karet

(Hevea

brasiliensis) adalah salah satu komoditi perkebunan penghasil devisa bagi Indonesia. Indonesia merupakan negara produsen karet terbesar kedua di dunia (Syukur dan Iswaramuda, 2015). Salah satu daerah penghasil karet di Indonesia adalah Provinsi Kepulauan Bangka Belitung. Menurut BPS Provinsi Kepulauan Bangka Belitung (2019), tanaman karet merupakan tanaman yang memiliki luasan lahan terbesar di Provinsi Kepulauan Bangka Belitung dibanding tanaman lainnya. Tanaman karet menjadi tanaman yang paling banyak dibudidayakan oleh masyarakat di Provinsi Kepulauan Bangka Belitung karena tanaman karet merupakan tanaman yang mudah dibudidayakan dan memiliki masa produksi yang panjang.

Luas lahan perkebunan karet di Provinsi Kepulauan Bangka tersebar di beberapa kabupaten, salah satunya adalah Kabupaten Bangka. Kabupaten Bangka merupakan salah satu sentra produksi tanaman karet di Provinsi Kepulauan Bangka Belitung, dengan luas lahan mencapai 21.854,62 $\mathrm{Ha}$ dengan produksi $50.236,11$ ton/tahun yang tersebar di beberapa kecamatan (BPS Kab. Bangka, 2021). Kecamatan Pemali merupakan salah satu kecamatan di Kabupaten Bangka yang memiliki potensi tanaman karet yang sangat besar. Kecamatan Pemali memiliki luas perkebunan karet rakyat sebesar $588 \mathrm{Ha}$, dengan produksi 555,4 ton (BPS Kab. Bangka, 2020).

Di masa sekarang ini, para pekebun karet di Kecamatan Pemali kurang bergairah dalam membudidaya tanaman karet dikarenakan harga bokar (bahan olah karet rakyat) yang rendah dan fluktuatif. Harga bokar pekebun yang rendah salah satunya disebabkan oleh mutu karet yang kurang baik. Mutu yang kurang baik ini salah satunya disebabkan oleh kebiasaan pekebun karet yang menggunakan bahan koagulan lateks yang tidak sesuai anjuran. Bahan koagulan lateks yang paling banyak digunakan oleh pekebun karet di Kecamatan Pemali Kabupaten Bangka adalah tawas. Penggunaan tawas sebagai bahan koagulan lateks dapat menyebabkan kualitas bokar (bahan olah karet rakyat) yang dihasilkan pekebun karet menjadi rendah. Penggunaan tawas sebagai bahan koagulan lateks tidak dapat menggumpalkan lateks dengan sempurna (Purbaya et al., 2011).

Pemerintah daerah melalui penyuluh pertanian memperkenalkan suatu inovasi untuk mengatasi permasalahan bokar pekebun yang 
rendah yaitu dengan penggunaan asam semut sebagai bahan koagulan lateks. Dengan penggunaan asam semut sebagai bahan koagulan lateks, akan didapatkan kualitas bokar (bahan olah karet) yang baik sesuai SNI 062047-2002 yaitu dicerminkan oleh Kadar Karet Kering (K3) dan tingkat kebersihan yang tinggi. Penggumpal anjuran seperti asam semut, formula asam organik, dan anorganik memiliki Po (plastisitas awal) lebih dari 30 dan PRI (plastisitas retensi indeks/indeks ketahanan plastisitas) lebih dari 50 yang sesuai dengan SIR (Standard Indonesia Rubber). Penggunaan asam semut juga mendapat KKK (Kadar Karet Kering) yang tinggi mencapai 84\% (Purbaya et al., 2011).

Suatu inovasi tidak akan berguna tanpa adanya adopsi. Demikian juga dengan penggunaan asam semut sebagai bahan koagulan lateks yang merupakan syarat agar bokar memiliki kualitas yang baik (Ulfah dkk, 2017). Dinas Pertanian Kabupaten Bangka sudah melakukan berbagai kebijakan untuk merubah kebiasaan pekebun di Kecamatan Pemali antara lain penyuluhan pertanian dan pemberian asam semut (asam formiat) gratis kepada pekebun. Berdasarkan hasil penyuluhan yang diberikan PPL di Kecamatan Pemali tentang penggunaan asam semut sebagai bahan koagulan lateks, hanya sebagian kecil pekebun saja yang mau mengadopsi inovasi tersebut.

Penggunaan asam semut sebagai bahan koagulan lateks tidak hanya memberikan keutungan kepada pekebun dari sisi kualitas bokar yang baik, akan tetapi juga menguntungkan pekebun dari sisi pendapatan. Adapun selisih harga jual untuk bokar yang menggunakan koagulan tawas dan koagulan asam semut yaitu $R p$ 1000,00 - Rp 2000,00 ditingkat pengepul. Dengan penggunaan asam semut yang baik dan tepat dosis maka akan memberikan keuntungan pendapatan kepada pekebun karena memiliki harga jual yang lebih tinggi.

Semakin banyak keuntungan yang didapatkan pekebun karet dalam penggunaan asam semut sebagai bahan koagulan lateks seharusnya semakin tinggi pula tingkat adopsi pekebun terhadap inovasi tersebut. Berdasarkan permasalahan diatas maka tujuan dari pelaksanaan penelitian ini yaitu untuk mengkaji :

a. Menganalisis tingkat adopsi pekebun karet terhadap penggunaan asam semut sebagai bahan koagulan lateks di Kecamatan Pemali. Kabupaten Bangka.

b. Menganalisis faktor-faktor yang berpengaruh signifikan dengan 
adopsi pekebun karet terhadap penggunaan asam semut sebagai bahan koagulan lateks di Kecamatan Pemali, Kabupaten Bangka.

\section{LANDASAN TEORI}

\section{Adopsi Inovasi}

Adopsi adalah keputusan untuk menggunakan sepenuhnya ide baru sebagai cara bertindak yang paling baik. Keputusan adopsi merupakan proses mental, sejak seseorang mengetahui adanya inovasi sampai mengambil keputusan untuk menerima atau menolaknya kemudian mengukuhkannya. Keputusan inovasi merupakan suatu tipe pengambilan keputusan yang khas (Fahrinoor dan Suprapto, 2004). Menurut Huda dkk (2014) mengartikan adopsi sebagai penerapan atau penggunaan sesuatu ide, alat-alat atau teknologi baru yang disampaikan berupa pesan komunikasi (lewat penyuluhan).

\section{Karakteristik Inovasi}

Rogers dalam Ahmad (2016) menyatakan bahwa karakteristik inovasi adalah sifat dari difusi inovasi yang terdiri dari 5 hal yaitu : relative advantage (keuntungan relatif), compatibility atau kompatibilitas (keserasian), complexity atau kompleksitas (kerumitan), trialability atau triabilitas (dapat diuji coba) dan observability (dapat diobservasi).

1) Relative Advantages (keuntungan relatif) adalah tingkat kelebihan suatu inovasi, apakah lebih baik dari inovasi yang ada sebelumnya atau dari hal-hal yang biasa dilakukan.

2) Compatibility atau kompatibilitas (keserasian) adalah tingkat keserasian dari suatu inovasi, apakah dianggap konsisten atau sesuai dengan nilai-nilai, pengalaman dan kebutuhan yang ada.

3) Complexity atau kompleksitas (kerumitan) adalah tingkat kerumitan dari suatu inovasi untuk diadopsi, seberapa sulit memahami dan menggunakan inovasi.

4) Triability atau triabilitas (dapat diuji coba) merupakan tingkat apakah suatu inovasi dapat dicoba terlebih dahulu atau harus terikat untuk menggunakannya.

5) Observability (dapat diobservasi) adalah tingkat bagaimana hasil penggunaan suatu inovasi dapat dilihat oleh orang lain.

\section{Saluran Komunikasi}

Rogers dalam Mulyandari (2003), menyatakan bahwa saluran komunikasi sebagai sesuatu yang dapat dimanfaatkan sumber maupun 
penerima untuk menyalurkan atau menyampaikan pesan-pesannya. Saluran komunikasi merupakan media yang dapat dimanfaatkan oleh individuindividu dan atau kelompok/organisasi yang berkomunikasi untuk menyampaikan

pesan-pesan (message). Saluran komunikasi merupakan elemen penting dan cukup untuk keberhasilan proses difusi inovasi. Penyampaian informasi,terdapat dua saluran komunikasi yaitu personal dan non personal (media massa).

1) Saluran komunikasi personal

2) Saluran komunikasi media massa

\section{Peran Penyuluh}

Proses adopsi dipengaruhi oleh aktivitas yang dilakukan oleh penyuluh, khususnya upaya yang dilakukan penyuluh untuk "mempromosikan" inovasi teknologi. Semakin rajin penyuluh menawarkan inovasi, maka semakin cepat inovasi dapat diadopsi oleh pekebun. Penyuluh pertanian memiliki peran dan tanggung jawab yang sangat besar, penyuluh harus mampu menyampaikan program pemerintah untuk kemajuan pertanian yang didukung dengan hasil penelitian. Penyuluh juga harus mampu menjadi fasilitator, motivator, komunikator dan edukator petani, sehingga petani dapat menerapkan hasil penelitian yang sesuai dengan kondisi lahan mereka.
Peran penyuluh terhadap

pengembangan pertanian yaitu :

1) Fasilitator, merupakan seseorang yang membantu sekelompok orang untuk memahami tujuan bersama.

2) Motivator, yaitu penyuluh pertanian diharapkan dapat mendorong dan menggerakkan pekebun agar mau menerapkan teknologi-teknologi terbaru yang dapat meningkatkan kesejahteraan pekebun.

3) Komunikator, yaitu penyuluh pertanian harus dapat menyampaikan pesan kepada pekebun.

4) Edukator, yaitu peranan penyuluh sebagai edukator diartikan sebagai kemampuan penyuluh dalam memberikan pelayanan kepada petani dalam setiap kegiatan berusahatani yang merupakan program penyuluhan oleh penyuluh.

\section{Peran Kelompok Tani}

Kelompok tani adalah kumpulan petani yang dibentuk atas dasar kesamaan, kepentingan, kondisi lingkungan, dan keakraban untuk meningkatkan dan mengembangkan usaha anggota. Kelompok tani memiliki fungsi yang sangat penting dalam pengembangan pertanian. Adapaun Fungsi Kelompok Tani menurut Parissing (2019) yaitu : 
1) Kelas Belajar : merupakan tempat atau wadah belajar mengajar sesama anggota dalam meningkatkan pengetahuan, keterampilan dan sikap anggota untuk tumbuh dan berkembang dalam berusaha meningkatkan produktivitas, pendapatan dan kehidupan yang sejahtra.

2) Wahana kerjasama : merupakan tempat memperkuat kerjasama, baik antara sesama anggota kelompok tani pun juga sesama kelompok tani atau pihak lain, sehingga usahatani lebih efisien dan mampu menghadapi ancaman, tantangan.

3) Unit Produksi : Usahatani dari setiap anggota kelompok merupakan satu kesatuan usaha yang dapat dikembangkan untuk mencapai skala ekonomi usaha dengan tetap menjaga kualitas, kuantitas dan keberlanjutan atau kontinuitas produksi.

\section{Sarana dan Prasarana}

Sarana adalah segala sesuatu yang dapat dipakai sebagai alat dan bahan untuk mencapai maksud dan tujuan dari suatu proses produksi. Sementara prasarana adalah segala sesuatu yang merupakan penunjang utama terselenggaranya produksi. Sarana dan prasarana yang baik dan memadai tentu dapat memperlancar kemajuan dalam sektor pertanian (Novianti et al., 2020).

\section{Lateks Tanaman Karet}

Lateks adalah cairan getah yang didapat dari bidang sadap pohon karet. Pada umumnya berwarna putih seperti susu dan belum mengalami penggumpalan dengan atau tanpa penambahan bahan pemantap (zat anti penggumpal) (Purbaya. et al.,2011). Cara untuk mendapatkan lateks dari tanaman karet yaitu melalui penyadapan. Penyadapan adalah pelukaan buatan yang diberikan pada kulit batang atau cabang tanaman karet (Syukur dan Iswaramuda, 2015).

\section{Asam Semut (Asam Format) Sebagai Bahan Koagulan Lateks}

Asam semut merupakan salah satu bahan koagulan lateks. Asam semut atau disebut juga asam format/formiat adalah asam karboksilat yang paling sederhana. Asam format secara alami terdapat pada antara lain sengat lebah dan semut. Asam format juga merupakan senyawa intermediet (senyawa antara) yang penting dalam banyak sintesis kimia. Rumus kimia asam format dapat dituliskan sebagai $\mathrm{HCOOH}$ atau $\mathrm{CH} 2 \mathrm{O} 2$. Tujuan dari penambahan asam adalah untuk menurunkan $\mathrm{pH}$ latek sehingga latek akan membeku atau berkoagulasi, yaitu pada $\mathrm{pH}$ antara 4.5-4.7. Asam format banyak 
digunakan sebagai asam penggumpal karena asam formiat mudah larut dalam air sehingga karet yang dihasilkan bermutu tinggi.

\section{METODE PENELITIAN}

Kajian ini dilaksanakan pada 29 Maret - 23 Mei 2021 di Kecamatan Pemali Kabupaten Bangka Provinsi Kepulauan Bangka Belitung yang merupakan sentra budidaya tanaman karet. Populasi dalam pengkajian adalah pekebun yang sudah pernah mendapatkan penyuluhan mengenai penggunaan asam semut sebagai bahan koagulan lateks yang berjumlah 154 pekebun karet. Teknik pengambilan sampel menggunakan metode purposive sampling. Sedangkan untuk menentukan jumlah responden dapat dihitung menggunakan rumus Slovin( Arrasyid dkk.,2018) :

$$
\sum \mathrm{n}=\frac{\mathrm{N}}{\mathrm{N}(\mathrm{e})^{2}+1}
$$

Keterangan:

$$
\begin{array}{ll}
\mathrm{n} & =\text { Jumlah Sampel } \\
\mathrm{N} & =\text { Jumlah Populasi } \\
\mathrm{e} & =\operatorname{error}(10 \%)
\end{array}
$$

Berdasarkan rumus diatas maka jumlah sampel digunakan adalah sebagai berikut:

$\sum \mathrm{n}=\frac{154}{154(10 \%)^{2}+1}$

$\mathrm{n}=60,6$ dibulatkan menjadi 61 orang
Teknik pengambilan data dilakukan dengan cara wawancara menggunakan kuesioner untuk mengetahui tingkat adopsi pekebun karet dan faktor-faktor yang mempengaruhi adopsi pekebun karet terhadap penggunaan asam semut sebagai bahan koagulan lateks. Teknik analisis data menggunakan analisis statistik deskriptif dan analisis regresi logistik. Variabel yang digunakan dalam penelitian ini meliputi umur $\left(\mathrm{X}_{1}\right)$, pendidikan $\left(\mathrm{X}_{2}\right)$, luas lahan $\left(\mathrm{X}_{3}\right)$, karakteristik inovasi $\left(\mathrm{X}_{4}\right)$, media komunikasi $\left(X_{5}\right)$, peran penyuluh $\left(X_{6}\right)$, sarana prasarana $\left(X_{7}\right)$, dan peran kelompoktani $\left(\mathrm{X}_{8}\right)$.

Tingkat adopsi pekebun karet terhadap penggunaan asam semut sebagai bahan koagulan lateks dilakukan dengan rumus (Juanidi dkk., 2016) sebagai berikut:

$\mathrm{N}=\frac{\text { jumlah responden menerapkan }}{\text { total responden }} \times 100 \%$

Kriteria perolehan nilai skor penelitian adalah :

1) $0 \%-20 \% \quad$ :Sangat Rendah

2) $21 \%-40 \% \quad$ : Rendah

3) $41 \%-60 \%$ : Sedang

4) $61 \%-80 \%$ : Tinggi

5) $81 \%-100 \%$ : Sangat Tinggi

Analisis data dilakukan dengan analisis regresi logistik. Pengujian pengaruh variabel secara parsial dapat dilakukan uji wald dengan kriteria tolak $\mathrm{H}_{0}$ apabila atau $p$-value $<\alpha$. Dengan $\alpha$ 
tingkat signifikasi $5 \%$. Jika $\mathrm{H}_{0}$ ditolak, artinya parameter tersebut berpengaruh signifikan secara statistik pada tingkat signifikasi $5 \%$.

\section{HASIL DAN PEMBAHASAN Karakteristik Responden}

Distribusi umur terbagi 5 kelompok, jumlah dan presentasi responden terdiri dari: kelompok 1 (2130 tahun, 5 orang, 8.2\%); kelompok 2 (31-40 tahun, 17 orang, $27.9 \%$ ); kelompok 3 (41-50 tahun, 22 orang, $36.05 \%$ ); kelompok 4 (51-60 tahun, 14 orang, $22.95 \%$ ), dan $>60$ tahun, 3 orang, $4.9 \%$ ). Berdasarkan data deskripsi diatas, responden paling banyak pada rentang usia 41-50 tahun dengan rata-rata umur responden 44 tahun. Responden yang berumur lebih dari 60 tahun hanya ada 3 orang. Menurut Badan Pusat Statistik (BPS, 2021), umur produktif rentang usia 15 60 tahun yang digolongkan usia produktif. Jadi dapat disimpulkan bahwa responden mayoritas memiliki usia yang produktif untuk bekerja diperkebunan karet.

Distribusi responden menurut tingkat pendidikan formal di Kecamatan Pemali, Kabupaten Bangka, terdiri dari: SD (21 orang, 34,4\%), SMP (23 orang, $37.7 \%$ ), SMA (13 orang, $21.3 \%$ ), dan Perguruan Tinggi (4 orang, 6.6\%). Pendidikan formal lebih didominasi responden yang sudah lulus Sekolah Menengah Pertama (SMP) sebanyak 23 responden atau dengan persentase $37,7 \%$. Data menunjukkan bahwa tingkat pendidikan responden sudah cukup bagus, bahkan 4 orang diantaranya sudah mengenyam pendidikan taraf perguruan tinggi. Pendidikan membuat seorang berpikir rasional,mengambil keputusan dengan berbagai alternatif ats masalah yang dihadapi (Husinsyah, 2014). Manakala, Yulianti (2015) menyatakan pendidikan mempengaruhi cara berpikir seseorang yang memiliki pengetahuan yang luas, mudah mengembangkan ide-ide, mudah mengadopsi teknologi dan dinamis menghadapi perubahan modern dalam bidang pertanian karet seperti proses penyadapan, pembentukan latek, marketing, dan lainnya.

Adapun distribusi responden berdasarkan luas lahan di Kecamatan Pemali, Kabupaten Bangka terdiri dari skala sempit $\quad<0.5 \mathrm{Ha}$, tidak ada terdeteksi; skala sedang (0.5-2.0 Ha, 59 orang atau $96.72 \%$ ) dan skala besar (>2.0 Ha, 2 orang atau $3.28 \%$ ). Hal ini menunjukkan bahwa luas lahan pekebun didominasi oleh luas lahan kategori sedang sebesar 0,5-2,0 $\mathrm{Ha}$ sebanyak 58 orang atau dengan persentase sebesar 96,72\%. Rata-rata luas lahan yang dimiliki responden 
adalah 1,37 Hektar. Kategori lahan di daerah responden termasuk dalam kategori skala sedang dan cukup memberikan keuntungan besar bagi pelaku usaha tani karet dalam hal produksi. Didukung penelitian Daniel (2002) menyatakan pemilikan atau penguasaan lahan sempit kurang efesien untuk menghasilkan produksi optimal dibandingkan dengan lahan yang lebih luas. Manakala Gustina (2014) mengemukakan penguasaan tanah bagi masyarakat merupakan unsur penting bagi meningkatkan kesejahteraannya.

Tingkat adopsi pekebun karet terhadap penggunaan asam semut sebagai bahan koagulan lateks

Berdasarkan hasil penelitian yang dilakukan di Kecmatan Pemali Kabupaten Bangka, jumlah pekebun karet yang menerapkan dan tidak menerapkan penggunaan asam semut sebagai bahan koagulan lateks dapat dilihat dalam tabel 1 berikut :

Tabel 1. Tingkat Adopsi Pekebun Karet Terhadap Penggunaan Asam Semut Sebagai Bahan Koagulan Lateks

\begin{tabular}{lc}
\hline \multicolumn{1}{c}{$\begin{array}{c}\text { Adopsi Asam } \\
\text { Semut }\end{array}$} & $\begin{array}{c}\text { Jumlah } \\
\text { Responden }\end{array}$ \\
\hline Pekebun & 14 \\
mengadopsi & \\
Pekebun tidak & \\
mengadopsi & 47 \\
\hline Total & 61 \\
\hline Sumber : Pengolahan Data Primer (2021)
\end{tabular}

Berdasarkan tabel 1 di atas, jumlah pekebun karet di Kecamatan
Pemali Kabupaten Bangka yang mengadopsi inovasi penggunaan asam semut sebagai bahan koagulan lateks adalah 14 responden. Sedangkan pekebun yang tidak mengadopsi penggunaan asam semut sebagai bahan koagulan lateks berjumlah 47 responden. Tingkat adopsi pekekebun karet terhadap penggunaan asam semut di Kecamatan Pemali Kabupaten Bangka dihitung menggunakan rumus berikut.

$\mathrm{N}=\frac{\text { jumlah responden menerapkan }}{\text { total responden }} \times 100 \%$

Sehingga diperoleh :

$$
\mathrm{N}=\frac{14}{61} \times 100 \%=22,95 \%
$$

Berdasarkan hasil perhitungan diatas, menunjukkan bahwa tingkat adopsi pekebun karet terhadap penggunaan asam semut sebagai bahan koagulan lateks di Kecamatan Pemali Kabupaten Bangka persentasenya sebesar 22,95 \%. Berdasarkan dengan kriteria penilaian, $22,95 \%$ masuk dalam kategori rendah. Adopsi pekebun karet terhadap penggunaan asam semut sebagai bahan koagulan lateks dalam kategori rendah karena pekebun karet sudah terbiasa melakukan koagulasi lateks dengan menggunakan tawas. Pekebun karet di Kecamatan Pemali Kabupaten Bangka menilai bahwa koagulasi menggunakan tawas lebih mudah dan 
menguntungkan. Pekebun karet di Kecamatan Pemali Kabupaten Bangka sadar bahwa penggunaan asam semut sebagai bahan koagulan lateks di Kecamatan Pemali Kabupaten Bangka membuat kualitas bokar menjadi lebih baik. Namun, pekebun karet menilai bahwa selisih harga jual bokar antara yang menggunakan asam semut dengan menggunakan tawas tidak terlalu jauh sehingga tidak terlalu memberikan keuntungan yang berarti.
Analasis faktor-faktor yang mempengaruhi pekebun karet terhadap penggunaan asam semut sebagai bahan koagulan lateks

Analisis faktor-faktor yang mempengaruhi pekebun karet terhadap penggunaan asam semut sebagai bahan koagulan lateks menggunakan uji wald. Hasil pengujian wald adopsi pekebun karet terhadap penggunaan asam semut sebagai bahan koagulan lateks di Kecamatan Pemali Kabupaten Bangka dapat dilihat pada tabel 2.

Tabel 2. Hasil Pengujian Wald

\begin{tabular}{|c|c|c|c|c|}
\hline Variabel & B & Sig. & $\begin{array}{l}\text { Odds } \\
\text { Ratio }\end{array}$ & Keterangan \\
\hline Umur & 0,061 & 0,441 & 1,062 & Tidak berpengaruh signifikan \\
\hline Pendidikan & $-0,061$ & 0,831 & 0,941 & Tidak berpengaruh signifikan \\
\hline Luas Lahan & 0,206 & 0,842 & 1,229 & Tidak berpengaruh signifikan \\
\hline $\begin{array}{l}\text { Karakteristik } \\
\text { Inovasi }\end{array}$ & 0,423 & 0,028 & 1,526 & Tidak berpengaruh signifikan \\
\hline Media Komunikasi & $-0,009$ & 0,968 & 0,991 & Tidak berpengaruh signifikan \\
\hline Peran Penyuluh & 0,525 & 0,037 & 1,691 & Berpengaruh signifikan \\
\hline $\begin{array}{l}\text { Sarana dan } \\
\text { Prasarana }\end{array}$ & 1,134 & 0,030 & 3,108 & Berpengaruh signifikan \\
\hline $\begin{array}{l}\text { Peran Poktan } \\
\text { Constant }\end{array}$ & $\begin{array}{r}0,261 \\
-38,160\end{array}$ & $\begin{array}{l}0,301 \\
0,002\end{array}$ & $\begin{array}{l}1,299 \\
0,000\end{array}$ & Tidak berpengaruh signifikan \\
\hline
\end{tabular}

Sumber : Pengolahan Data Primer (2021)

Dari hasil analisis regresi logistik didapatkan persamaan regresi logistic berikut ini:

$\operatorname{Ln} \frac{\mathrm{p}}{1-p}=-38,160+0,061 X 1-0,061 \times 2+0,206 \times 3+0,423 \times 4-0,009 \times 5+0,525 \times 6+1,134 \times 7+0,261 \times 8+\mathrm{e}$

\section{Pengaruh variabel umur terhadap peluang adopsi pekebun karet menggunakan asam semut}

Nilai signifikan untuk variabel umur sebesar 0,441 dimana nilai signifikan lebih besar dari a $(0,441>$ 0,05), maka terima $\mathrm{H}_{0}$ tolak $\mathrm{H}_{1}$, artinya bahwa variabel umur $\left(\mathrm{X}_{1}\right)$ tidak berpengaruh terhadap peluang adopsi pengunaan asam semut sebagai bahan koagulan lateks (Y). Hal ini menunjukkan bahwa semakin tinggi atau tua umur pekebun belum tentu semakin tinggi peluang adopsi terhadap terhadap pengunaan asam semut sebagai bahan koagulan lateks. Artinya adopsi pengunaan asam semut sebagai bahan koagulan lateks dapat diterapkan oleh siapa saja tanpa 
membedakan umur. dapat diterapkan oleh siapa saja tanpa membedakan umur. Hasil ini sejalan dengan pendapat (Rahmasari et al., 2020), yang menyatakan bahwa umur tidak berpengaruh signifikan terhadap penentuan keputusan petani dalam mengadopsi inovasi. Hal ini dikarenakan, baik petani muda maupun petani tua belum tentu bersemangat dan cepat dalam melakukan adopsi inovasi.

\section{Pengaruh variabel pendidikan terhadap peluang adopsi pekebun karet menggunakan asam semut \\ Nilai signifikan dari variabel} pendidikan sebesar 0,831 dimana nilai signifikan lebih besar dari a $(0,831>$ 0,05), maka terima $\mathrm{H}_{0}$ tolak $\mathrm{H}_{1}$, artinya bahwa variabel pendidikan $\left(\mathrm{X}_{2}\right)$ tidak berpengaruh terhadap peluang adopsi pekebun karet terhadap penggunaan asam semut sebagai bahan koagulan lateks di Kecamatan Pemali Kabupaten Bangka. Pengaruh yang tidak signifikan antara pendidikan dengan peluang adopsi pekebun karet terhadap penggunaan asam semut sebagai bahan koagulan lateks di Kecamatan Pemali, Kabupaten Bangka menunjukkan bahwa apapun tingkat pendidikan formal petani, baik yang tingkat pendidikannya rendah ataupun tinggi memiliki kesempatan yang sama dalam menerapkan pengunaan asam semut sebagai bahan koagulan lateks. Inovasi penggunaan asam semut sebagai bahan koagulan lateks merupakan inovasi yang tidak terlalu sulit sehingga tidak membutuhkan pendidikan yang tinggi untuk paham dan mampu menerapkan asam semut sebagai bahan koagulan lateks.

Hasil ini sejalan dengan penelitian Effendy et al., (2020) yang menyatakan bahwa pendidikan tidak berpengaruh signifikan terhadap adopsi inovasi. Hal ini dikarenakan, tinggi rendahnya tingkat pendidikan petani tidak akan mempengaruhi keputusan petani untuk mengadopsi inovasi baru karena untuk menerapkan suatu teknologi dalam usahataninya, petani tidak harus memiliki tingkat pendidikan yang tinggi. Dimana tidak semua petani berpendidikan tinggi memiliki keterampilan dan pengetahuan yang lebih tinggi dibandingkan petani yang tingkat pendidikannya rendah.

\section{Pengaruh variabel luas lahan terhadap peluang adopsi pekebun karet menggunakan asam semut}

Nilai signifikan dari variabel luas lahan sebesar 0,824 dimana nilai signifikan lebih besar dari a $(0,824>$ $0,05)$, maka terima $\mathrm{H}_{0}$ tolak $\mathrm{H}_{1}$, artinya bahwa variabel luas lahan $\left(X_{3}\right)$ tidak berpengaruh terhadap peluang adopsi pekebun karet terhadap penggunaan 
asam semut sebagai bahan koagulan lateks di Kecamatan Pemali Kabupaten Bangka (Y). Pengaruh yang tidak signifikan antara luas lahan dengan peluang adopsi pekebun karet terhadap penggunaan asam semut sebagai bahan koagulan lateks menunjukkan bahwa luas lahan tidak mempengaruhi pekebun karet dalam mengadopsi penggunaan asam semut sebagai bahan koagulan lateks. Pekebun karet yang mempunyai lahan yang luas maupun kecil memiliki peluang yang sama dalam menerapkan penggunaan asam semut sebagai bahan koagulan lateks di Kecamatan Pemali, Kabupaten Bangka. Hal ini dikarenakan penggunaan asam semut sebagai bahan koagulan lateks dapat dilakukan pada perkebunan karet petani dengan luasan lahan kecil maupun besar.

Hasil ini sejalan dengan penelitian Rahmasari et al., (2020) yang menyatakan luas lahan tidak berpengaruh terhadap keputusan petani dalam adopsi yang berarti bahwa jumlah luasan lahan yang diusahakan petani tidak menjadi tolak ukur, dalam artian memang petani yang memiliki luasan lahan kecil memiliki kecenderungan enggan menerapkan teknologi yang tidak biasa.
Pada umumnya petani dengan lahan yang kurang luas dan mayoritas pengelolaannya adalah dilakukan sendiri menjadikan petani sangat hatihati dan selektif untuk menerapkan suatu inovasi baru karena kekuatiran akan kegagalan yang berimbas pada menurunnya tingkat keuntungan. Tetapi ternyata fakta lain dilapangan juga menunjukan bahwa petani dengan lahan yang luas pun tidak akan selalu memiliki kecenderungan untuk mudah menerapkan suatu inovasi baru.

\section{Pengaruh variabel karakteristik inovasi terhadap peluang adopsi pekebun karet menggunakan asam semut}

Nilai signifikan dari variabel karakteristik inovasi sebesar 0,028 dimana nilai signifikan lebih kecil dari $\alpha$ $(0,028<0,05)$, maka tolak $\mathrm{H}_{0}$ terima $\mathrm{H}_{1}$, artinya bahwa variabel karakteristik inovasi $\left(\mathrm{X}_{4}\right)$ berpengaruh signifikan terhadap peluang adopsi pekebun karet menggunakan asam semut sebagai bahan koagulan lateks di Kecamatan Pemali Kabupaten Bangka (Y). Nilai koefisien regresi variabel karakteristik inovasi adalah 0,423 dan bernilai positif atau searah yang menunjukkan semakin besar pengaruhnya terhadap peluang adopsi pekebun karet menggunakan asam semut sebagai bahan koagulan lateks di Kecamatan Pemal, Kabupaten Bangka. Hal ini karena karakteristik 
inovasi mempengaruhi keputusan petani untuk mengadopsi asam semut sebagai bahan koagulan lateks. Menurut (Rogers, 2003) bahwa semakin baik karakteristik dari sebuah inovasi yang akan diterapkan maka semakin cepat petani memutuskan untuk mengadopsi inovasi tersebut.

Hasil ini sejalan dengan penelitian Rahmasari et.al, (2020) yang menyatakan karakteristik inovasi teknologi berpengaruh secara siginifikan terhadap adopsi inovasi. Karakteristik inovasi berpengaruh signifikan karena pada umumnya petani pasti mencari cara yang dianggap paling menguntungkan untuk diterapkan. Petani akan lebih cepat mengadopsi inovasi setelah petani merasakan adanya manfaat langsung dari teknologi yang berupa keuntungan relatif (termasuk keuntungan ekonomi yang lebih tinggi), kesesuaian teknologi terhadap nilai sosial budaya, dan kerumitan penerapan teknologi.

Hasil serupa juga dikemukakan oleh penelitian Effendy et al., (2020) yang menyatakan sifat inovasi berpengaruh nyata dengan tingkat adopsi teknologi. Karakteristik inovasi yaitu berupa tingkat keuntungan, tingkat kerumitan, tingkat kesesuaian, kemungkinan untuk dicoba dan kemungkinan untuk diamati. Suatu inovasi akan dapat diterima oleh petani apabila secara teknis dapat dilaksanakan, ekonomis menguntungkan dan secara sosiologis dapat dipertanggungjawabkan. Apabila memang benar teknologi baru akan memberikan keuntungan yang relatif besar dari teknologi lama, maka kecepatan proses adopsi inovasi akan berjalan lebih cepat.

Variabel karakteristik inovasi bertanda positif menunjukkan bahwa peningkatan persepsi pekebun karet terhadap karakteristik inovasi memiliki kecenderungan untuk mengadopsi inovasi penggunaan asam semut sebagai bahan koagulan lateks. Nilai odds ratio sebesar 1,526 menunjukkan bahwa semakin tinggi persepsi pekebun karet terhadap karakteristik inovasi hasil penggunaan asam semut sebagai bahan koagulan lateks, akan meningkatkan kecenderungan pekebun karet mengadopsi inovasi penggunaan asam semut sebagai bahan koagulan lateks sebesar 1,526 kali.

\section{Pengaruh variabel media komunikasi terhadap peluang adopsi pekebun karet menggunakan asam semut}

Nilai signifikan dari variabel media komunikasi sebesar 0,982 dimana nilai signifikan lebih besar dari $\alpha(0,982>0,05)$, maka terima $\mathrm{H}_{0}$ tolak $\mathrm{H}_{1}$, artinya bahwa variabel media komunikasi $\left(\mathrm{X}_{5}\right)$ tidak berpengaruh signifikan terhadap peluang adopsi pekebun karet terhadap penggunaan 
asam semut sebagai bahan koagulan lateks di Kecamatan Pemali Kabupaten Bangka (Y). Berdasarkan hasil observasi di lapangan, pekebun karet mendapatkan informasi mengenai inovasi penggunaan asam semut sebagai bahan koagulan lateks didapatkan hanya dari saluran komunikasi personal yaitu melalui penyuluh dan pekebun lain. Selain itu, pekebun karet dalam melakukan usahatani karet selalu bertumpu dari pengalaman mereka sendiri. Pekebun karet di Kecamatan Pemali, Kabupaten Bangka belum memanfaatkan saluran komunikasi non personal atau media masa seperti internet, leaflet, dan media komunikasi non personal lainnya.

Namun ada juga pekebun karet yang frekuensi akses saluran komunikasinya tinggi tetapi tetap tidak menerapkan penggunaan asam semut sebagai bahan koagulan lateks karena walaupun pengetahuan mereka tentang inovasi tersebut banyak tetapi kesadaran untuk beralih menggunakan asam semut sebagai bahan koagulan lateks masih rendah. Pekebun karet tersebut tetap menggunakan tawas sebagai koagulan lateks karena dianggap lebih praktis dan sudah biasa mereka gunakan selama ini.

$$
\text { Hasil ini sejalan dengan }
$$

pengkajian Akbar et al (2018) bahwa akses media komunikasi tidak berpengaruh secara signifikan terhadap adopsi dikarenakan masih jarang sekali petani mengakses informasi pertanian lewat akses media komunikasi non-personal atau media massa, kebanyakan petani mendapatkan informasi melalui penyuluhan ataupun dari petani lain serta rapat kelompok tani yang diadakan satu bulan sekali.

\section{1) Pengaruh variabel peran penyuluh terhadap peluang adopsi pekebun karet menggunakan asam semut}

Nilai signifikan dari peran penyuluh sebesar 0,032 dimana nilai signifikan lebih kecil dari a $(0,032<$ $0,05)$, maka tolak $\mathrm{H}_{0}$ terima $\mathrm{H}_{1}$, artinya bahwa variabel peran penyuluh $\left(X_{6}\right)$ berpengaruh signifikan terhadap peluang adopsi pekebun karet menggunakan asam semut sebagai bahan koagulan lateks di Kecamatan Pemali, Kabupaten Bangka (Y).Nilai koefisien regresi peran penyuluh adalah 0,525 dan bernilai positif atau searah, yang menunjukkan semakin besar nilai variabel peran penyuluh maka semakin besar pengaruh peran penyuluh terhadap adopsi pekebun karet menggunakan asam semut sebagai bahan koagulan lateks di Kecamatan Pemali Kabupaten Bangka. Penyuluh pertanian memiliki peran yang sangat penting dalam adopsi inovasi oleh petani khususnya 
inovasi penggunaan asam semut sebagai bahan koagulan lateks. Inovasi penggunaan asam semut sebagai bahan koagulan lateks diperkenalkan oleh penyuluh pertanian kepada pekebun karet. Menurut (Fauziyah, 2010) menyatakan bahwa intensitas penyuluhan pertanian sangat dibutuhkan dalam meningkatkan usaha tani. Penyuluh memiliki kemampuan, terampil dan cekatan dalam mengajarkan suatu hal. Penyuluh juga berperan sebagai fasilitator (membantu memahami tujuan bersama), motivator (mendorong dan menggerakkan petani agar mau mengadopsi inovasi teknologi pertanian), komunikator (menyampaikan informasi dengan jelas dan lengkap) dan inovator (mengenalkan inovasi teknologi pertanian yang sesuai dengan karakteristik wilayah).

Hasil ini selaras dengan pengkajian yang dilakukan oleh Khamdani, (2017) yang menyatakan bahwa kecepatan adopsi ditentukan oleh aktivitas yang dilakukan penyuluh terutama untuk mempromosikan inovasi teknologi pertanian. Semakin rajin penyuluh menawarkan inovasi teknologi maka, semakin cepat pula proses adopsi terjadi. Penyuluh berperan untuk menyampaikan program pemerintah demi kemajuan pertanian yang didukung dengan hasil penelitian. Penyuluh juga berperan sebagai fasilitator, motivator, komunikator dan educator.

Variabel peran penyuluh bertanda positif menunjukkan bahwa peningkatan peran penyuluh memiliki kecenderungan pekebun karet untuk mengadopsi inovasi penggunaan asam semut sebagai bahan koagulan lateks lebih tinggi pula. Nilai odds ratio sebesar 1,691 menunjukkan bahwa semakin tinggi peran penyuluh, akan meningkatkan kecenderungan pekebun karet mengadopsi inovasi penggunaan asam semut sebagai bahan koagulan lateks sebesar 1,691 kali.

\section{Pengaruh variabel sarana prasarana terhadap peluang adopsi pekebun karet menggunakan asam semut} Nilai signifikan untuk variabel sarana dan prasarana sebesar 0,047 dimana nilai signifikan lebih kecil dari $\alpha$ $(0,047<0,05)$, maka tolak $\mathrm{H}_{0}$ terima $\mathrm{H}_{1}$, artinya bahwa variabel sarana dan prasarana $\left(X_{7}\right)$ yang meliputi ketersediaan dan kemudahan dalam mendapatkan saprodi berpengaruh secara signifikan terhadap peluang adopsi pekebun karet mengunakan asam semut sebagai bahan koagulan lateks $(\mathrm{Y})$.

Suatu inovasi harus didukung oleh ketersediaan sarana dan prasarana yang lengkap, salah satunya adalah ketersediaan asam semut itu 
sendiri. Apabila sarana produksi sulit didapat atau bahkan tidak tersedia maka akan menyulitkan petani untuk mencoba atau bahkan mengadopsi inovasi. Ketersediaan sarana dan prasarana mendukung kelancaran petani dalam mengadopsi teknologi, sehingga dapat mempengaruhi keputusannya untuk mengadopsi teknologi baru (Hanafie, 2010).

Berdasarkan hasil observasi di lapangan, ketersediaan sarana dan produksi sudah cukup lengkap. Akan tetapi ketersediaan asam semut masih sulit didapatkan di kios-kios saprodi di Kecamatan Pemali, Kabupaten Bangka. Kenyataannya, tingkat adopsi asam semut yang masih rendah sehingga permintaan asam semut sebagai bahan koagulan lateks juga rendah. Masih sedikit kios saprodi yang menjual asam semut.

Sulitnya mendapatkan asam semut berdampak kepada susahnya pekebun karet yang ingin mencoba menggunakan asam semut sehingga pekebun karet tidak bisa membuktikan sendiri bahwa penggunaan asam semut memberikan dampak yang lebih baik untuk kualitas bokar mereka. Sejalan dengan pendapat Siwu Randi A.A, (2018) menyatakan bahwa sarana dan prasarana pertanian menjadi sumber utama dalam pengembangan suatu inovasi pertanian oleh sebab itu, sarana dan prasarana harus dipenuhi dalam mendukung kemajuan di sektor pertanian.

Variabel sarana dan prasarana bertanda positif menunjukkan bahwa peningkatan sarana dan prasarana memiliki kecenderungan pekebun karet untuk mengadopsi inovasi penggunaan asam semut sebagai bahan koagulan lateks lebih tinggi pula. Nilai odds ratio sebesar 3,108 menunjukkan bahwa semakin baik sarana dan prasarana, akan meningkatkan kecenderungan pekebun karet mengadopsi inovasi penggunaan asam semut sebagai bahan koagulan lateks sebesar 3,108 kali.

\section{Pengaruh variabel peran kelompok tani terhadap peluang adopsi pekebun karet terhadap penggunaan asam semut}

Nilai signifikan untuk variabel peran kelompok tani sebesar 0,463 dimana nilai signifikan lebih besar dari $\alpha(0,463>0,05)$, maka terima $\mathrm{H}_{0}$ dan tolak $\mathrm{H}_{1}$, artinya bahwa variabel peran kelompok tani $\left(\mathrm{X}_{8}\right)$ tidak berpengaruh secara signifikan terhadap peluang adopsi pekebun karet meengunakan asam semut sebagai bahan koagulan lateks $(\mathrm{Y})$.

Berdasarkan hasil observasi di lapangan, pekebun karet di Kecamatan Pemali Kabupaten Bangka dalam melakukan usahatani tanaman karet belum memanfaatkan peran kelompoktani dengan baik sebagai 
kelas belajar dan wahana kerjasama dalam peningkatan kualitas dan kuantitas hasil produksi dari tanaman karet mereka. Peran kelompoktani bagi pekebun karet di Kecamatan Pemal, Kabupaten Bangka hanya sebatas formalitas sehingga dapat memudahkan para pekebun karet untuk mendapatkan bantuan dari pemerintah.

\section{KESIMPULAN DAN SARAN}

Berdasarkan analisis dan pembahasan yang mengkaji tentang adopsi pekebun karet terhadap penggunaan asam semut sebagai bahan koagulan lateks di Kecamatan Pemali Kabupaten Bangka maka dapat ditarik kesimpulan yaitu:

1. Tingkat adopsi pekebun karet terhadap penggunaan asam semut sebagai bahan koagulan lateks di Kecamatan Pemali Kabupaten Bangka tergolong rendah dengan persentase (22,95\%).

2. Variabel yang berpengaruh signifikan terhadap adopsi penggunaan asam semut yaitu variabel karakteristik inovasi, peran penyuluh, dan saranaprasarana sebagai bahan koagulan lateks. Sedangkan variabel umur, pendidikan, luas lahan, media komunikasi dan peran kelompoktani tidak berpengaruh signifikan terhadap adopsi penggunaan asam semut sebagai bahan koagulan lateks.

Berdasarkan kesimpulan yang telah didapat, adapun saran yang dapat diberikan oleh penulis adalah sebagai berikut:

1. Diharapkan kepada penyuluh pertanian yang ada di Kecamatan Pemali Kabupaten Bangka dapat meningkatkan penyuluhan kepada pekebun karet khususnya mengenai penggunaan asam semut sebagai bahan koagulan lateks.

2. Pemerintah diharapkan memberikan bantuan sarana dan prasarana berupa asam semut sebagai bahan koagulan lateks kepada pekebun karet agar para pekebun mudah untuk menerapkan penggunaan asam semut sebagai bahan koagulan lateks di Kecamatan Pemali Kabupaten Bangka.

\section{DAFTAR PUSTAKA}

A.A, Siwu, Randi. (2018). Dampak Program Bantuan Sarana Produksi Pertanian Terhadap Pendapatan Petani Cabai Di Desa Kauneran Kecamatan Sonder. Jurnal Transdisiplin Pertanian 14(3), 8142

Ahmad, M., Y. (2016). Pengaruh Karakteristik Inovasi Pertanian Terhadap Keputusan Adopsi Usahatani Sayur Organik. Agrosience, 6, 1 - 14. 
Akbar, M. I., Suminah, \& Wibowo, A. (2018). Faktor-faktor yang Berpengaruh Terhadap Keputusan Adopsi Inovasi Kalender Tanam Terpadu di Kecamatan Gedang Sari Kabupaten Gunung Kidul. Jurnal Agritexts 429(2), 133-145.

Arrasyid, A., D. Rohmat, Jupri, S., Himayah, A., R. Affriani, R., Ridwana (2018). The Suggest of Rubber Crops Cultivation Development Zonation at West Bandung Regency. IOP Conf. Series: Earth and Environmental Science 286 (2019) 012029 IOP Publishing doi:10.1088/17551315/286/1/012029 1-10.

BPS Kab. Bangka. (2021). Kabupaten Bangka dalam Angka 2021. Sungailiat: Badan Pusat Statistik Kab. Bangka.

BPS Kab. Bangka. (2020). Kecamatan Pemali dalam Angka 2020. Sungailiat: Badan Pusat Statistik Kab. Bangka.

BPS Prov.Babel. (2019). Provinsi Kep. Bangka Belitung dalam Angka 2019. Pangkalpinang: Badan Pusat Statistik Prov.Babel.

Daniel, Moehr. (2002). Pengantar Ekonomi Pertanian. Jakarta: Bumi Aksara.

Effendy, L., \& Pratiwi, S. D. (2020). Tingkat Adopsi Teknologi Sistem Jajar Legowo Padi Sawah di Kecamatan Cigasong Kabupaten Majalengka. Jurnal Agricia Ekstensia, 8-14.

Fahrinoor, T., dan Suprapto. (2004). Komunikasi Penyuluhan dalam Teori dan Praktek. Yogyakarta: Arti Bumi Lintasan.

Fauziyah, E. (2010). Analisis Efisiensi Teknis Usahatani Tembakau (Suatu Kajian dengan menggunakan fungsi produksi Frontier Stokhastik). EMBRYO, 915.

Gustina, Desy. (2014). Pengaruh Luas Lahan Terhadap Pendapatan Petani Karet di Desa Pulau Ingu, Kecamatan Benai, Kabupaten uUantan, Singingi, 1-8.

Junaidi, Rosnita, Kausar. (2016). Analisis Modal Sosial pada Keberdayaan Petani Karet (Studi Kasus Petani Karet di Kecamatan Logas Tanah Darat Kabupaten Kuantan Singingi). Jom Faperta 3 (1), 1-9.

Hanafie, R. (2010). Pengantar Ekonomi Pertanian. Yogyakarta: CV. Andi Offset.

Huda, Nurul. Budi Suharjo dan Ani Suryani. (2013). Adopsi Teknologi Budi Daya dan Strategi Pengembangan Perkebunan Karet Rakyat di Kecamatan Teweh Tengah Kabupaten Barito Utara. Manajemen IKM 8(2), 135143.ISSN 2085-8418 http://journal.ipb.ac.id/index.php/jur nalmpi/

Harlan, J. (2018). Analisis Regresi Logistik. Depok: Penerbit Gunadarma.

Husinsyah. (2014). Konstribusi Petani Karet Terhadap Petani Kampung di Kecamatan Mencimal. e-Jurnal EP-UNUD, 3(1), 9-20

Khamdani, R. (2017). Peranan Penyuluh Pertanian Lapangan dalam Adopsi Teknologi Jajar Legowo di Kecamatan Sewon Kabupaten Bantul. Yogyakarta: Universitas Muhammadiyah Yogyakarta.

Mardikanto, T., dan Sri Sutanti. (1982). Pengantar Penyuluhan Pertanian. Surakarta: Hapsara. 
Novianti, S., Kusmiyati, dan Dwiwanti Sulistyowati. (2020). Adopsi Inovasi Penggunaan Varietas Unggul Baru Padi Sawah di Kecamatan Cilaku Kabupaten Cianjur Provinsi Jawa Barat. Jurnal Inovasi Pertanian, 1(4), 22-26.

Parissing, C. S. (2019). Fungsi dan Peran Kelompoktani. Dipetik Maret Kamis, 2020, dari Cybex Pertanian: http://cybex.pertanian.go.id/ mobile/artikel/85489/KELOMPOKTANI--FUNGSI-DAN-PERANKELOMPOK-TANI/

Purbaya, M., Sari, T. I., Saputri, C. A., \& Fajriati, M. T. (2011). Pengaruh Beberapa Jenis Bahan Penggumpal Lateks dan Hubungannya Dengan Susut Bobot, Kadar Karet Kering, dan Plastisitas. Prosiding Seminar Nasional AVoER ke-3 (hal. 351357). Palembang: Fakultas Teknik Universitas Sriwijaya.

Rahmasari, F. N., Kunadi, D., \& Harniati. (2020). Pengaruh
Penyuluhan Terhadap Keputusan Petani Dalam Adopsi Teknologi Pengendalian Hama Terpadu Padi Sawah di Kecamatan Cikalongkulon. Jurnal Inovasi Penelitian.

Rogers, E. (2003). Diffusion of Innovation. New York: Free Pres.

Syukur dan Iswaramuda, W. (2015). Penyadapan Tanaman Karet. Jambi: Balai Pelatihan Pertanian Jambi.

Ulfah, D., N.M. Sari, Y.Puspita. (2017). Pengaruh Campuran Asam Semut DEngan Asap Cair Cangkang Kelapa Sawit Terhadap Bau dan Waktu Kecepatan Beku Lateks Karet (Hevea brasiliensis Muell.Arg). Jurnal Hutan Tropis 2, 17-21 ppjp.ulm.ac.id

Yulianti, Ansopino, Jolianis (2015). Analisis Faktor-Faktor Yang Mempengaruhi Masyarakat Transmigrasi di Trans Sakato Jaya, Kecamatan Sungai Aur, Kabupaten Pasaman Baray, 1-9. 